\title{
The Effect of Product-Harm Crises on the Financial Value of Firms under the Concept of Green Development
}

\author{
Songsong Li, Yaopan Yang $(\mathbb{D}$, and Dong Zhang \\ School of Management, Harbin Institute of Technology, Harbin, China \\ Correspondence should be addressed to Yaopan Yang; yangyaopan@hit.edu.cn
}

Received 23 December 2020; Revised 9 February 2021; Accepted 24 February 2021; Published 12 March 2021

Academic Editor: Wei Zhang

Copyright (C) 2021 Songsong Li et al. This is an open access article distributed under the Creative Commons Attribution License, which permits unrestricted use, distribution, and reproduction in any medium, provided the original work is properly cited.

\begin{abstract}
Product-harm crises can trigger product recalls or product discards, which is very likely to cause secondary pollution to the environment. Also, these crises may harm customers' health and threaten firms' survival. To foster low-carbon economy and green development in such complex systems, this paper studies the internal mechanism of the product crisis and its impact on the firm value. It proposes a two-stage model to avoid the endogeneity of product-harm crises. In the first stage, this paper assesses the effect of firms' leverage on their capacity to produce higher quality products. In the second stage, this paper conducts the impact of these crises on stock prices. Then, it depicts the financial effects of product-harm crises over time, and analyzes the differences of such effects based on brand equity. Results show that book leverage can positively impact firms' capacity to produce high-quality products. In addition, the market's response to product-harm crises is significant at $1 \%$ level, and with the increase in severity, the market reaction is more prominent. Furthermore, its negative effect is persistent for a firm experiencing a severe crisis. Luckily, brand equity can mitigate this negative impact. These findings provide some ways to improve product performance and firm value in the green context.
\end{abstract}

\section{Introduction}

The Chinese government advocates harmonious coexistence between humans and nature, and sticks to the path of green and sustainable development. A huge amount of related work has been conducted $[1,2]$. However, limited productharm work has been conducted under the concept of green development. When a product-harm crisis occurs, it causes product recalls or product discards, resulting in a secondary pollution to the environment. The secondary pollution goes against the company's low-carbon economy and green development. Also, a product-harm crisis is potential for customers' economic loss, serious illness or injury, and even death [3]. Moreover, the crisis can affect a firm's reputation and value, and interrupt the supply and financial chain, leading to its bankruptcy, such as the Sanlu group $[4,5]$. In such a complex context, it is worth exploring the underlying mechanism and external influence of the product-harm crisis.

The product-harm crisis is a knotty issue created by defective or dangerous products $[6,7]$. As shown in a previous study [8], the episode of a product-harm crisis includes initial negative event, firm's recovery strategy, and post-recovery. Much work has been done in the firm's recovery field, including the analysis of product recalls [9-12], the classification of firms' behavior [13-15], and the analysis of brand attributes [16-19]. However, limited work has been conducted in the stage of initial negative events, such as the type of crises or the severity of crises [8].

Furthermore, lots of recent work has focused on firms or investors $[10,11,20]$, although early product-harm work focused on consumers $[19,21,22]$. The reason is that the overall effect of these crises is reflected in the stock returns immediately and directly [23]. Such an effect reveals investor perceptions of firm value [24]. As seen in the recent case of the Changsheng group (http://news.windin.com), the dangerous lyophilized human rabies vaccine has caused many infants to be disabled or even die. Following that, its stock price plunged sharply, from 24.55 yuan to 1.51 yuan, a drop of nearly 94 percent.

Research has found that most studies concerning the impact of product-harm crises are limited to developed 
countries [25]. Still, some industries with frequent productharm crises receive much less attention (e.g., clothing and information technology industries). Thus, this paper includes a variety of industries from China. It covers 208 cases from different industries, such as medicine products, machinery equipment, clothing, food, as well as information technology industry. Then, the paper examines the factor and effect of the incidence and severity of initial crises.

In addition, regarding the product-harm work, the majority treats time as a control factor, and not much literature considers the impact of such crises over time [8]. Therefore, it is valuable to depict the financial effect of product-harm crises over time. Moreover, extant work of product-harm crisis has to pay much attention to brandrelated mediators. But, the findings are contradictory [18]. These two contradictory findings are as follows: brand equity buffers the negative effect affected by a crisis $[3,19,21,26]$, and brand equity is a trouble in the case of a crisis [27, 28]. From a new perspective, the investors' standpoint, this paper can provide a new evidence for the buffer effect of brand equity, by analyzing the differences in the negative effect between high brand equity and low brand equity.

In a nutshell, this paper aims to examine the internal factors and financial effects of incidence and severity of product-harm crises from a wide range of industries in a developing country. This paper firstly considers financial leverage influencing product-harm crises to address the endogenous issue. By doing so, it provides more conclusive and persuasive evidence that supports negative market reaction to initial product-harm crises. This paper then pictures the financial impact of these crises over time. Furthermore, through analyzing the differences in financial impact of most severe crises, this study finds that high brand equity can mitigate this financially negative effect.

\section{Hypothesis}

The effect of product-harm crises is reflected in the stock market directly. Extant studies have explored the financial effect of product-harm crises from different viewpoints. Firstly, from the perspective of industry, it is discussed that the fluctuations of stock prices in different industries after the product recall, especially in the automotive and pharmaceutical industries [4, 29-31]. Secondly, from the characteristics of the firm, the impact of product-recall strategies or CEO characteristics on the stock price of the firm has been discussed [11, 20,32]. Thirdly, from the characteristics of crisis, such as the severity of product recall, the literature explores the impact of crisis characteristics on stock price movements [23].

Almost all these studies identify product-harm crises by product recalls and encompass the field of firm's recovery. However, as developing countries lack sound rules and regulations, the cases of product recalls per year are very limited. Research has only found 42 cases of product recalls from various industries in China, spanning 10 years [4]. Among these product recalls, 20 cases were in the automobile industry. Furthermore, limited product-harm work has focused on the initial negative events. Thus, this paper focuses on the initial product-harm crises amid the green development scenario. The top priority is to study the internal factors of product-harm crises. Then, it examines the negative impact of such crises and to find effective solutions based on firm characteristics.

\subsection{Financial Conditions Contributing to Product-Harm} Crises. Some firms are more likely to experience productharm crises due to their inherent characteristics. A string of articles prove that financial leverage may boost investments in firms, which will reduce the probability of such crises. Brander and Lewis [33] have suggested that leverage usage to shareholders can provide risk-shifting incentives at the expense of benefits to bondholders. By doing so, managers have the motivation to take out debt and increase their investments in firms to get a strategic advantage over their industry counterparts [34]. Furthermore, financially poor firms improve their investments through money subsided by debt holders. As a consequence, these firms are more likely to get out of financial trouble and produce high product quality in the future using "someone else's money" [35]. In addition, another benefit of levered firms is that leverage can motivate managers and their organizations to be more competitive in operational management and more attentive to product market concerns [36]. Specially, debt taking forces managers to bond their promises to debt service payments. The threat posed by crises to repay debt is an effective motivation to make these managers and organizations more effective, thus leading to high product quality. These theoretical predictions have been supported by the empirical evidence presented by Campello and Fluck [37], which shows that firms with more debt have outperformed their industry counterparts. Thus, the following hypotheses are proposed:

Hypothesis 1a: the incidence of product-harm crises is negatively related to the financial leverage.

Hypothesis $1 \mathrm{~b}$ : the severity of product-harm crises is negatively related to the financial leverage.

\subsection{The Impact of Product-Harm Crises on Stock Prices of} Firms. A product-harm crisis means that there are problems in the firm's production and operation process. Such a crisis can seriously damage a firm's image. Even worse, the quality of the product and the underlying information behind it will hit investors' confidence, which will immediately be reflected in the stock price. Thus, these investors make negative expectations about the development of the firm based on signal theory [38]. Then, investors will throw out their shares of the firm, which will lead to a decline in the stock price. What's more, investors' reaction to damage is more drastic than the reaction to an equivalent earnings, supported by the prospect theory [39]. Applied to product-harm crises, it is expected that investors focus more on potential losses than on potential gains in revenues [40]. Based on investors' loss aversion, this paper assumes that the incidence of product-harm crisis is negatively associated with stock prices. 
Furthermore, the severity of product-harm crises is the degree of potential harm resulting from a product hazard. Rogers has noted that people will take more intense measures to protect themselves from external harm as the risks they face increase, suggested by the theory of protection motivation [41]. As a source of risk for consumers, productharm crises will undoubtedly cause psychological panic and worry among the public. This psychological state leads to the unsalable products of the involved firm and the decline of the market position. In addition, a serious hazard is more likely to get much media attention $[28,42]$. It conveys more frequent and vivid signals to consumers about harm to their health, resulting in greater circumspection about purchasing products from the affected firm. Investors incorporate these messages, intensified by their loss aversion, into their assessment of sales in the future [23]. Thus, the following hypotheses are proposed:

Hypothesis 2a: the incidence of product-harm crises is related to a negative stock market response.

Hypothesis 2b: the more severe the product-harm crises, the more negative the stock market response will be.

\section{Sample Construction and Data Characteristics}

3.1. Sample Construction. This paper identifies productharm crises by searching the Wind database, China Food and Drug Administration (CFDA), State Administration for Market Regulation (SAMR), and Sina. We include A-share listed corporations from 2014 to 2017. The sample of firms needs to be China based and either listed on the Shanghai Stock Exchange (SHSE) or the Shenzhen Stock Exchange (SZSE). Stock prices are secured from the CSMAR database.

This paper then reports the distribution of sample by year in Panel A, industry in Panel B, and manufacturing industry in Panel C of Table 1. Panel A comprises 207 final samples. Of these, $34.78 \%$ of the samples occurred in 2017. Some firms have undergone more than one product-harm crisis during 2014-2017. Regarding the distribution of industries, manufacturing industry is the top list with the most reported subindustries. Thus, it represents the subindustry distribution of the manufacturing sector in Panel C. And, there are 9 two-level INC industries (industry classification code) in manufacturing sector. The frequency of events occurring in $\mathrm{C} 8, \mathrm{C} 7, \mathrm{C} 1$, and $\mathrm{C} 0$ industries decreases successively.

\subsection{Data Characteristics of Product-Harm Crises and Control} Firms. Table 2 reports univariate comparisons between product-harm crises and control firms on the basis of financial condition and other variables that can impact product-harm crises [43] and CARs [44]. The variables that could impact product-harm crises include Book leverage, Size, Sales, and the Number of suppliers [43-45]. Other variables that can impact CARs consist of $\mathrm{R} \& \mathrm{D}$ intensity, Book to market, and Net income. More specially, Book leverage, Size, Sales, R \& D intensity, Book to market, and Net income are calculated at the end of the previous year and are obtained from the CSMAR database. The number of suppliers is obtained from the WIND database.

Table 2 reports the univariate comparisons between product-harm samples and control samples. The sample period is 2014-2017. Control samples are the firms that belong to the same 3-level INC industry (industry classification code) as the product-harm firm provided and they were not announced with product-harm crises during 2014-2017. The total assets of control firms are similar to that of product-harm firms. T-Stat provides the t-statistic from a $t$-test for equality in means between the productharm firms and control firms. Z-Stat provides the Z-statistic for the equality of medians between the product-harm firms and control firms. ${ }^{* * *},{ }^{* *}$, and ${ }^{*}$ indicate significance at $1 \%$, $5 \%$, and $10 \%$, respectively.

Of all these, Book leverage represents the sum of the long-term debt and debt in current liabilities divided by total assets. The logarithm of the total asset is regarded as a proxy for firm size. Sales represents the logarithm of sales as an indicator for firm's continuing income. Number of suppliers presents the number of key suppliers of the firm, which is obtained from the WIND database. Because it is difficult to get the number of suppliers of the firm every year, this paper assumes that the number of suppliers is constant in different years. R \& D intensity is defined as R \& D spending over total assets.

Book to market is the firm's book-to-market ratio as an indicator for the firm's value. High Book to market means high value and low growth, and vice versa. Net income is the logarithm of net income from operating activities, which represents a net sustainable income.

In Table 2, the univariate statistics on the variables for product-harm crises and control firms are presented. Control firms are firms belonging to the same 3-level INC industries as the product-harm firms with a similar total asset but have not experienced a product-harm crisis in any of the years during 2014-2017. This paper then performs a $t$ test to test for the equality of means between the productharm samples and control samples. A Wilcoxon rank-sum test is also performed to test for the equality of medians. As a result, this paper finds that product-harm firms have significantly higher Size, Sales, and Net income than control firms.

\section{Market Reaction upon Announcement of Product-Harm Crises}

Event study methodology (ESM) [46-49] is a well-established approach that has been widely applied to assess the effect of particular events on firms or investors, such as product recalls $[32,43]$, merger and acquisition announcements [50], CEO scandals [44], and banking crises [51]. Therefore, this paper utilizes ESM to assess the impact of product-harm crises on stock returns in China [4].

In essence, an unexpected event is observed to generate significant abnormal stock returns (AR), which indicate the market's estimate of a firm's value in the future. The 
TABLE 1: Frequency of product-harm crises and industries covered in product-harm sample.

\begin{tabular}{|c|c|c|c|c|}
\hline \multicolumn{5}{|c|}{ A: frequency of product-harm crises by crisis type } \\
\hline Year of product-harm crises & Freq. & Percent & \multicolumn{2}{|c|}{ Cum. } \\
\hline 2014 & 38 & 18.27 & \multicolumn{2}{|c|}{18.27} \\
\hline 2015 & 55 & 26.44 & \multicolumn{2}{|c|}{44.71} \\
\hline 2016 & 72 & 34.62 & \multicolumn{2}{|c|}{79.33} \\
\hline 2017 & 43 & 20.67 & \multicolumn{2}{|c|}{100.00} \\
\hline 2014-2017 & 208 & 100.00 & \multicolumn{2}{|c|}{100.00} \\
\hline \multicolumn{5}{|c|}{ B: industries covered in product failure sample at 1-level INC level } \\
\hline 1-level INC & Description of industry & Number of product-harm crises & Percent & Cum. \\
\hline A & Agricultural & 1 & 0.48 & 0.48 \\
\hline $\mathrm{C}$ & Manufacturing industry & 165 & 79.71 & 80.19 \\
\hline $\mathrm{D}$ & Water production and supply & 2 & 0.97 & 81.16 \\
\hline G & Information technology industry & 19 & 9.18 & 90.34 \\
\hline $\mathrm{H}$ & Whole income and retail trade & 18 & 8.70 & 99.03 \\
\hline J & The real estate industry & 1 & 0.48 & 99.52 \\
\hline $\mathrm{M}$ & Comprehensive industry & 1 & 0.48 & 100 \\
\hline \multicolumn{5}{|c|}{ C: industries covered in manufacturing product failure sample at 2-level INC level } \\
\hline $\mathrm{CO}$ & The food and beverage industry & 19 & 11.52 & 11.52 \\
\hline $\mathrm{C} 1$ & Textile clothing and fur & 29 & 17.58 & 29.10 \\
\hline $\mathrm{C} 3$ & Paper and printing & 1 & 0.61 & 29.71 \\
\hline $\mathrm{C} 4$ & Petroleum, chemicals, and plastics & 18 & 10.91 & 40.62 \\
\hline C5 & Electronic engineering & 1 & 0.61 & 41.23 \\
\hline C6 & Metal and nonmetal & 11 & 6.67 & 47.90 \\
\hline $\mathrm{C} 7$ & Machinery, equipment, and instrumentation & 32 & 19.39 & 67.29 \\
\hline $\mathrm{C} 8$ & Medicine and biological products & 52 & 31.52 & 98.81 \\
\hline $\mathrm{C} 9$ & Other manufacturing & 2 & 1.21 & 100 \\
\hline
\end{tabular}

In Table 1, panel A presents the frequency and percent of product-harm crises in our product-harm sample by public traded corporations during $2014-2017$. Panel B shows the different 1-level INC (industry classification code) industries covered in our product-harm sample, as well as the number and percent of product-harm crises under each 1-level INC industry. Panel C reports the different 2-level INC (industry classification code) industries covered in our manufacturing product-harm sample, as well as the number and percent of product-harm crises under each 1-level INC industry.

TABLE 2: Univariate comparisons between product failure samples and control firms.

\begin{tabular}{|c|c|c|c|c|c|c|c|c|c|}
\hline \multirow{2}{*}{ Variable } & \multicolumn{4}{|c|}{ Product failure sample } & \multicolumn{4}{|c|}{ Control sample } & \multirow{2}{*}{$\mathrm{T}(\mathrm{Z})$ Stat } \\
\hline & Obs & Mean & Median & S.D. & Obs & Mean & Median & S.D. & \\
\hline Book leverage & 207 & 0.393 & 0.360 & 0.181 & 207 & 0.400 & 0.393 & 0.198 & $-0.390(0.241)$ \\
\hline Size & 207 & 22.703 & 22.554 & 1.189 & 207 & 22.591 & 22.417 & 1.128 & $-5.092^{* * *}\left(-4.853^{* * *}\right)$ \\
\hline Sales & 207 & 22.413 & 22.168 & 1.355 & 207 & 22.014 & 21.970 & 1.297 & $-7.270^{* * *}\left(-6.848^{* * *}\right)$ \\
\hline Number of suppliers & 180 & 3.222 & 3.000 & 2.244 & 170 & 3.741 & 5.000 & 2.392 & $1.601(1.624)$ \\
\hline R \& D intensity & 195 & 0.021 & 0.015 & 0.054 & 185 & 0.020 & 0.016 & 0.015 & $-0.487(0.916)$ \\
\hline Book to market & 199 & 0.813 & 0.543 & 0.748 & 207 & 0.803 & 0.535 & 0.844 & $-0.067(-0.756)$ \\
\hline Net income & 188 & 19.966 & 20.035 & 1.431 & 176 & 19.666 & 19.795 & 1.539 & $-2.931^{* * *}\left(-2.669^{* * *}\right)$ \\
\hline
\end{tabular}

advantage of ESM is that it identifies stock price volatilities due to a firm-specific event [52]. Utilizing ESM, this paper calculates abnormal returns (AR) of the product-harm crisis, which reflect the financial impact of such an event. The value of Abnormal returns (AR) is measured as the difference between actual returns and expected returns around the time of the event. Cumulative abnormal returns (CARs) reflect the cumulative effects of the firm-specific event. When the value of CARs is negative, it indicates that the event is unfavorable. In this case, the event usually leads to the prediction of negative future profitability.

To test the market reaction to the incidence and severity of product-harm crises, this paper uses the event study methodology. The earliest announced day of product-harm crisis is treated as the event date. Then, it measures
Cumulative Abnormal Returns (CARs) over a few days around the publicity of product-harm crises. The value of CARs is the sum of the abnormal returns during our windows of interest. Since many product-harm crises are first discovered before public date, the information has been leaked to the market before being made public. This paper then computes CARs prior to the event date to cover for the news leakage. Thus, the windows include $(-5,+1),(-10,+1)$, $(-10,+5),(-1,+10)$, and $(-10,+10)$, with day 0 representing the day that the product-harm crisis is made public.

To predict forecasted daily returns, this paper uses four approaches as given below. The paper firstly utilizes the Fama-French three-factor model to predict daily returns [53]. Then, it computes the abnormal return for firm $i$ on day $t\left(A R_{i t}\right)$ as given below. 


$$
A R_{i t}=R_{i t}-\left(\alpha R P_{t}+\beta S M B_{t}+\chi H M L_{t}+R F_{t}\right) .
$$

$R_{i t}$ is the return of firm $i$ on day $t . R P_{t}$ is the market risk premium factor, the difference between the daily market return rate of the cash dividend reinvestment (the total market capitalization weighted average method) and the daily risk-free interest rate (the central bank announces the three deposit benchmark interest rate). $S M B_{t}$ (small minus big) is the result of the returns of small-stock portfolios minus the returns of big-stock portfolios. $H M L_{t}$ (high minus low) is the difference between the returns of high and low book-to-market equity portfolio with about the same weighted average size. $R F_{t}$ is the daily risk-free interest rate. Because the change of $R F$ is small, the biggest change is only $0.004 \%$ during our sample period of 2014-2017; this paper assumes that it is constant. $\alpha, \beta$ and $\gamma$ are parameters to estimate. The model is evaluated by utilizing the daily returns over the estimation period $(-200$, $-11)$ as presented in

$$
R_{i t}=\alpha R P_{t}+\beta S M B_{t}+\gamma H M L_{t}+R F_{t}+\varepsilon_{j t} .
$$

Second, the research also calculates CARs using the method of Fama-French five-factor model to predict daily returns [24]. This model is constructed by adding two factors to the Fama-French three-factor model. The two additional factors are profitability and investment factors.

In addition, this paper uses the average of the daily returns over the estimation period $(-200,-11)$ as forecasted returns to measure CARs [44]; calling it the e-period model here. Furthermore, the market model is utilized to predict daily returns. This paper then computes the abnormal return for firm $i$ on day $t\left(A R_{i t}\right)$ as follows:

$$
A R_{i t}=R_{i t}-\left(\alpha R P_{t}+\beta R_{m t}\right) .
$$

$R_{i t}$ is the return of firm $i$ on day $t, R_{m t}$ is the return of the CSMAR equally weighted Index, $\alpha$ and $\beta$ are parameter estimates. The model is estimated using daily returns over the period $(-200,-11)$ as presented in

$$
R_{i t}=\alpha R P_{t}+\beta R_{m t}+\varepsilon_{i t} .
$$

Next, product-harm crises are classified into three categories referring to FDA (U.S. FOOD \& DRUG ADMINISTRATION) severity classification criteria. Class I events are the least severe; Class II events can induce temporary, medically reversible adverse health consequences or major financial loss; and Class III events being the most severe are likely to induce adverse health consequences or death [43]. For events that are not sufficiently detailed, the paper cannot judge the severity from the announcements and do not classify them. Then, two subsamples are obtained, one including Class II and Class III, and the other including Class III only. A $t$-test is performed to test for the means of CARs equal to zero, containing the whole sample and two subsamples, respectively. Panel A of Table 3 presents the means and $t$-test of CARs. More specifically, this paper measures CARs for event periods surrounding the public dates of the product-harm crises. Findings demonstrate that the mean CARs are negative across all the event periods, either for the whole sample or for the other two subsamples. Of the 60 mean CARs, 59 are significant at the $10 \%$ level or better and 31 are significant at the $1 \%$ level. Thus, the negative CARs confirm the hypothesis that investors respond unfavorably to public product-harm crises. For the overall sample of product-harm crises, 9 of the 20 mean CARs are significant at the $1 \%$ level. For the subsample of Class II \& Class III, 10 of the 20 mean CARs are significant at the $1 \%$ level. For the subsample of Class III, 12 of the 20 mean CARs are significant at the $1 \%$ level. This supports the fact that severity of product-harm crises can contribute to CARs.

However, results find that the mean CARs computed by the Fama-three model and the Fama-five model are not affected by severity of product-harm crises. Furthermore, for overall samples, their $(-1,+10)$ event windows have mean CARs of $-2.187 \%,-2.400 \%$, respectively, with the highest $t$-Stat. But the mean CARs by the e-period model and market model are contributed by severity of productharm crises. For product-harm samples, their $(-5,+1)$ event windows have mean CARs of $-1.800 \%,-1.963 \%$, respectively, with the highest $t$-Stat. To further verify whether the severity of product-harm crises has an impact on stock price anomalies, a nonparametric test, Kruskal-Wallis, is performed to test CARs computed by the e-period model and the market model. The results are presented in panel B of Table 3, which also support the fact that severity of product-harm crises can contribute to CARs.

Moreover, this paper needs to disentangle the impact of the financial condition, firm size, sales, and the number of suppliers from incidence/severity of the product-harm crises to determine the true effect of the latter on the firm's share price. This paper then uses the two-stage procedure to control for this endogenous issue. In the first stage, a probit regression model and an ordered probit regression model are applied, respectively, to estimate the propensity that a firm is influenced by incidence/severity of product-harm crises. In the second stage, this paper derives the R \& D intensity, Book to market, and Net income that are employed in the crosssectional analysis of the CARs.

4.1. The Likelihood Being Affected by Product-Harm Crises. Firstly, the hypotheses about the factors that impact the incidence/severity of product-harm crises are empirically investigated. The main models are probit regressions and ordered probit regressions, respectively. They are shown as follows: 
TABle 3: Announcement effects of product-harm crises.

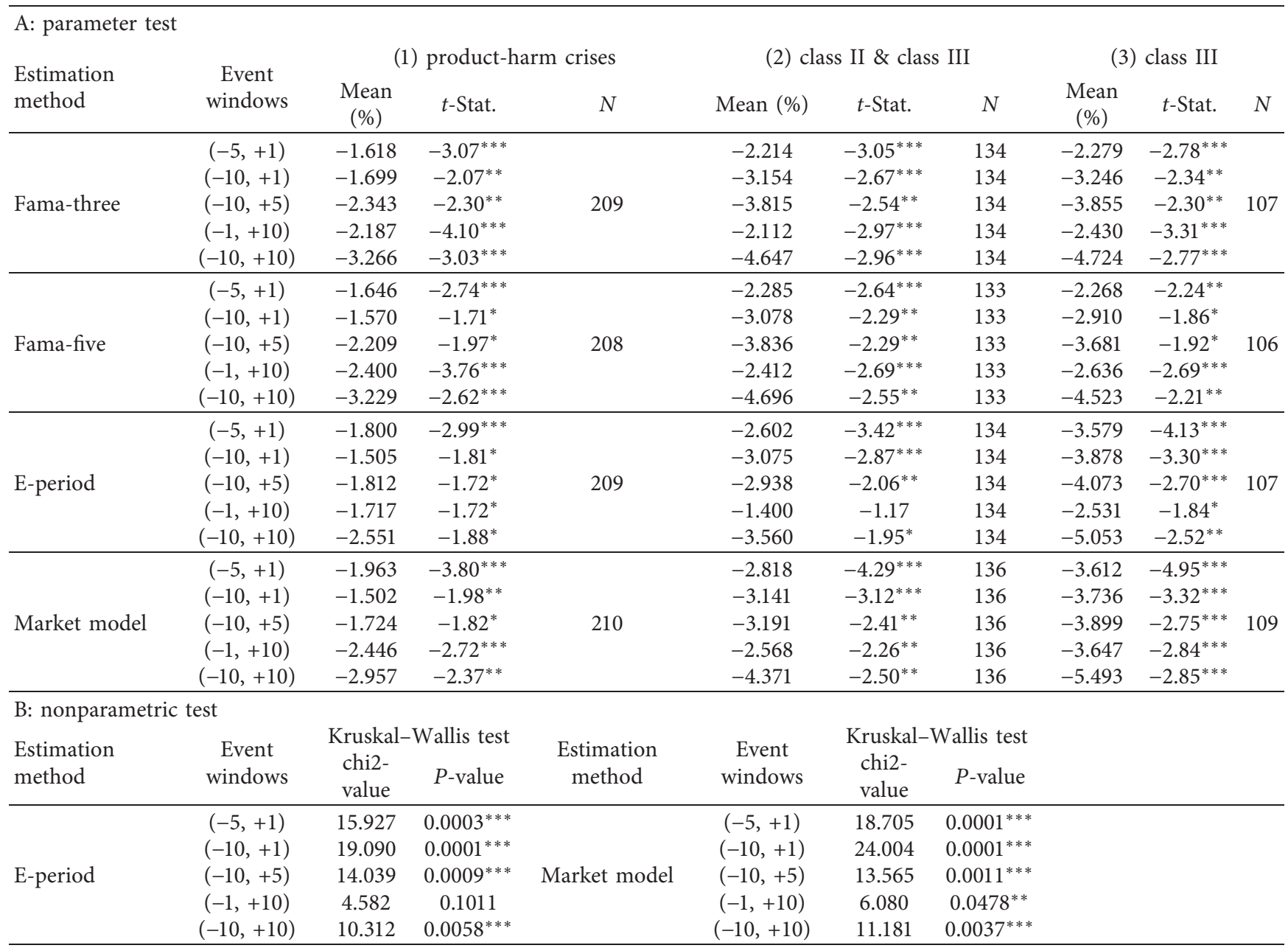

In panel A, CARs are shown for the windows in days around the event date. The windows are as follows: $(-5,+1),(-10,+1),(-10,+5),(-1,+10)$, and $(-10$, $+10)$. In methods 1 and 2 , this paper utilizes Fama-French three-factor model and Fama-French five-factor model, respectively. In addition, it uses E-period and Market model in methods 3 and 4. In panel B, Kruskal-Wallis is employed to test the impact of severity of product-harm crises on stock price anomalies, which is calculated from e-period model and market model.

$\frac{\text { Incidence }_{i, t}}{\text { Severity }_{i, t}}\left(\frac{\text { Incidence }_{i, t}=0,1}{\text { severity }_{i, t}=0,1,2,3}\right)=\alpha_{0}+\alpha_{1}$ Book leverage $_{i, t-1}+\alpha_{2}$ Size $_{i, t-1}+\alpha_{3}$ Sales $_{i, t-1}+\alpha_{4}$ Number of suppliers $_{i, t-1}$

$$
+\frac{\text { Year and }}{\text { or industry dummies }}+\varepsilon_{i, t}
$$

In the above model, the dependent variables are Incidence and Severity, respectively. Incidence is a dummy variable that takes the value 1 if a product-harm crisis occurs for firm $i$ in year $t$, and 0 for control firms in our sample. Severity is a dependent variable, which is set to 1 for Class I events (the least severe product-harm crises), 2 for Class II events, 3 for Class III events (the most severe product-harm crises), and 0 for control firms in our sample. All independent variables are lagged by one year to help ease concerns about reverse causality [43].

The regression results are presented in Table 4. Columns (1) and (4) include Book leverage, Size, Sales, and calendar year dummies. Number of suppliers is added in Columns (2) and (5), and 1-level INC industry dummy is added in Columns (3) and (6). The table shows marginal effects with their $P$-values in parentheses. These $P$-values are based on heteroskedasticity robust standard errors and are clustered by firm. The results are showed in the six columns.

Specifically, results find that the relation between the Incidence/Severity and book leverage is negative in all models. The coefficient is higher when the model includes Number of suppliers and 1-level INC industry dummies in Columns (3) and (6). Such results imply that higher leverage 
TABLE 4: The likelihood being affected by incidence/severity of product-harm crises.

\begin{tabular}{|c|c|c|c|c|c|c|}
\hline \multirow{2}{*}{ Dep. variables } & \multicolumn{3}{|c|}{ Incidence } & \multicolumn{3}{|c|}{ Severity } \\
\hline & $(1)$ & $(2)$ & (3) & $(4)$ & (5) & $(6)$ \\
\hline Book leverage & $\begin{array}{c}-0.836^{*} \\
(0.084) \\
\end{array}$ & $\begin{array}{c}-1.035^{*} \\
(0.067) \\
\end{array}$ & $\begin{array}{c}-1.037^{*} \\
(0.068) \\
\end{array}$ & $\begin{array}{l}-0.669 \\
(0.159) \\
\end{array}$ & $\begin{array}{c}-0.924^{*} \\
(0.086) \\
\end{array}$ & $\begin{array}{c}-0.995^{*} \\
(0.071) \\
\end{array}$ \\
\hline Size & $\begin{array}{c}-0.468^{* * *} \\
(0.004)\end{array}$ & $\begin{array}{c}-0.402^{* *} \\
(0.028)\end{array}$ & $\begin{array}{c}-0.402^{* *} \\
(0.030)\end{array}$ & $\begin{array}{c}-0.387^{* * *} \\
(0.006)\end{array}$ & $\begin{array}{c}-0.345^{* *} \\
(0.029)\end{array}$ & $\begin{array}{c}-0.351^{* *} \\
(0.026)\end{array}$ \\
\hline Sales & $\begin{array}{c}0.566^{* * *} \\
(0.000) \\
\end{array}$ & $\begin{array}{c}0.541^{* * *} \\
(0.001)\end{array}$ & $\begin{array}{c}0.541^{* * *} \\
(0.001)\end{array}$ & $\begin{array}{c}0.505^{* * *} \\
(0.000) \\
\end{array}$ & $\begin{array}{c}0.495^{* * *} \\
(0.000)\end{array}$ & $\begin{array}{c}0.496^{* * *} \\
(0.000)\end{array}$ \\
\hline Number of suppliers & & $\begin{array}{l}-0.052 \\
(0.209)\end{array}$ & $\begin{array}{l}-0.052 \\
(0.210)\end{array}$ & & $\begin{array}{l}-0.046 \\
(0.221)\end{array}$ & $\begin{array}{l}-0.047 \\
(0.216)\end{array}$ \\
\hline Year dummies & Yes & Yes & Yes & Yes & Yes & Yes \\
\hline Industry dummies & No & No & 1-level INC & No & No & 1-level INC \\
\hline Observations & 413 & 350 & 350 & 407 & 343 & 343 \\
\hline Wald & $\begin{array}{l}17.96^{* * *} \\
(0.0063)\end{array}$ & $\begin{array}{l}15.74^{* *} \\
(0.0276)\end{array}$ & $\begin{array}{c}15.81^{* *} \\
(0.0453)\end{array}$ & $\begin{array}{c}558.07^{* * *} \\
(0.0000)\end{array}$ & $\begin{array}{c}553.29^{* * *} \\
(0.0000)\end{array}$ & $\begin{array}{c}530.31^{* * *} \\
(0.0000)\end{array}$ \\
\hline
\end{tabular}

Table 4 presents estimation results of the incidence and severity for product-harm events by listed firms during 2014-2017. The dependent variables are incidence and severity. Incidence is a dummy variable, which is set to 1 for firms in the product-harm sample, and 0 for control firms. Severity is an ordered rank variable, which is set to 1, 2, or 3 for firms in the product-harm sample according to the severity of the event, and 0 for control firms. Columns (1) and (4) contain estimation results when they include Book leverage, Size, Sales, and calendar year dummies. Columns (2) and (5) contain estimation results when they add Number of suppliers. Columns (3) and (6) contain estimation results when they add 1-level INC industry dummies. Marginal effects are presented in the table. Presented $P$-values in the parentheses are based on heteroskedasticity robust standard errors. These $P$-values are clustered by firm. ${ }^{* * *}$, ${ }^{* *}$, and * indicate significance at $1 \%, 5 \%$, and $10 \%$, respectively.

for China' firms can hinder the incidence of failures and degrade the hazard of crises. These findings are consistent with the view that higher debt can help firms get out of financial trouble, and get a strategic advantage over their industry counterparts. These findings also agree with the notion that higher leverage may motivate managers and their organizations to be more efficient in operational management and more attentive to product market concerns, which lead to higher product quality. Our hypothesis $1 \mathrm{a}$ and $1 \mathrm{~b}$ are supported by these.

Furthermore, there is a significant negative relation between the Incidence/Severity and Size in all models. The smaller firms are more likely to have product-harm crises and their severity is higher. An explanation for this is that a large firm might have more to lose from product-harm crises than a smaller firm, and may therefore have stricter product quality control processes than smaller firm. Hence, the probability and severity of product-harm crises decrease in larger firms compared to smaller firms. Results then find that there exists a positive relation between the Incidence/Severity and Sales. Higher sales may imply greater production output, increasing the probability of incidence and severity for product-harm crises. Finally, results do not find a relation between the incidence/severity of product-harm crises and the Number of suppliers.

\subsection{The Short-Term CARs Being Affected by Product-Harm Crises}

4.2.1. CARs Being Affected by Product-Harm Crises. Results find that the mean CARs computed by the Famathree model and the Fama-five model are not affected by severity of product-harm crises. For overall samples, their $(-1,+10)$ event windows have mean CARs of $-2.187 \%$, $-2.400 \%$, respectively, with the highest $t$-Stat. Thus, this section uses $(-1,+10)$ CARs computed by the Fama-three model and the Fama-five model as dependent variables. But the mean CARs calculated by the e-period model and the market model are contributed by severity of product-harm crises. For product-harm samples, their $(-5,+1)$ event windows have mean CARs of $-1.800 \%,-1.963 \%$, respectively, with the highest $t$-Stat. Therefore, this section uses $(-5,+1)$ CARs computed by the e-period model and the market model as dependent variables.

Multiple regression analysis is employed to account for the variations in the CARs as presented in equation (6). The regression enables us to establish whether the variable incidence/severity of product-harm crises is significantly associated with the CARs after controlling for other firm characteristics. It is expected that the value of the coefficient of incidence/severity is significantly negative. This negative coefficient reflects the unfavorable share price reaction to public product-harm crises.

$$
\begin{aligned}
\text { CARs }_{i, t}= & \alpha_{0}+\frac{\alpha_{1} \text { Incidence }_{i, t}}{\text { Severity }_{i, t}}+\alpha_{2} \text { Book to market }_{i, t-1}+\alpha_{3} \text { R\&D intensity }_{i, t-1} \\
& +\alpha_{4} \text { Net income }_{i, t-1}+\frac{\text { Year and }}{\text { or industry dummies }}+\varepsilon_{i, t} .
\end{aligned}
$$


In equation (6), Book to market is the firm's book-to-market ratio, an indicator for firm's value-low-value firms are related to low book-to-market, and vice versa. $\mathrm{R} \& \mathrm{D}$ intensity is the research \& development spending divided by total assets. Net income is the logarithm of net operating income. Book to market, R \& D intensity, and Net income are calculated at the end of the prior year and downloaded from the CSMAR database. R \& D intensity and Net income are included in control variables.

4.2.2. Cross-Sectional Analysis of CARs. As product-harm crises may be attributed to various factors including the financial condition, firm size, sales, and the number of suppliers, there exist a self-selection issue in product-harm samples. For instance, a firm with small size is more likely to have a product-harm crisis, thus making it more likely to be included in the sample. By examining the impact of productharm crises on CARs, this section would have introduced a risk of endogeneity into the analysis, caused by potentially omitted variables that could affect the predicted variable. If the endogeneity cannot be statistically corrected, biased coefficient estimates and faulty conclusions will follow [54]. To address this potential endogenous problem, this section uses the two-step regressions approach [55]. Table 5 presents the findings of the two-step regressions on the firms' CARs [56].

In the first stage, this section estimates the probability of a firm being affected by incidence/severity of a productharm crisis, based on model (3) and model (6) from Table 4. In the second stage, the dependent variables $(-1,+10)$ CARs is from the Fama-French three-factor model and the Fama-French five-factor model in Columns (1) and (2). Then $(-5,+1)$ CARs are computed by the e-period model and the market model as dependent variables in Columns (3) and (4). Incidence/Severity is an endogenous variable. Incidence is set to 1 for firms in the product-harm crises sample, and 0 for the control sample. Severity is set to 1 for Class I events (the least severe product-harm crises), 2 for Class II events, 3 for Class III events (the most severe product-harm crises), and 0 for control firms in our sample. Book to market, R \& D intensity, and Net income are included as exogenous variables in the CARs regressions. R \& $\mathrm{D}$ intensity and Net income are regarded as control variables. Panel A contains results from the 2nd stage of the twostage estimation utilizing book leverage, size, sales, and the number of suppliers as instruments from Panel B. All estimations include year dummies and 1-level INC industry dummies.

The primary focus is Incidence, which is employed to test whether the product-harm crisis elicits an unfavorable share price reaction. Results show that there exists a negative relation between the CARs and the likelihood of a productharm crisis. Its coefficient is significantly different from zero at $5 \%$ in both Columns (1) and (2). This confirms that the incidence of product-harm crises is related to negative CARs, which also supports the univariate results reported earlier in Table 3.

The second focus is Severity, which is established to test whether the severity of product-harm crisis elicits an unfavourable stock market reaction. The coefficient of Severity is consistently negative and significant at least at $5 \%$ in Columns (3) and (4). This confirms that the severity of product-harm crises is related to negative CARs and also supports the univariate results reported earlier in Table 3. The finding means that a serious event is more likely to cause a fall in share price. Furthermore, results find that the relation between the CARs and Book to market is positive and significant at the $10 \%$ level in Column (4). This suggests that value firms can relieve the effect of the severe hazard and growth firms deepen it. This is because growth firms' products are often early in their product life cycle, with uncertain revenues in the future [23]; investors react more strongly to it when such a firm experiences a product-harm crisis. Meanwhile, this result is consistent with the value effect concept, which believes that value stocks outperform growth stocks globally.

\subsection{The Differences in Negative Effect Affected by Product- Harm Crises}

4.3.1. The Duration of the Negative Effect Based on Crisis Severity. To further explore whether the effect of the product crises is temporary or permanent, this section has examined the duration of the negative effect based on its severity Since Class II has a small number of samples, we put Class I and Class II in the second group. Cumulative average abnormal returns (CAARs) of Class I, Class II and Class II, and Class III are plotted across event time for the event windows $(-5$, $90)$ in Figure 1. The figure shows that the stock price fell upon publicity of the product-harm crisis. But the pattern of CAARs diverged by severity of product-harm events. For firms experiencing a Class I event (the least severe), their stock prices stopped decreasing after 60 days. A similar pattern was found for the second group (Class I and Class II), although the decline in stock prices halted at about 70 days. The nadir of its CAARs was roughly -0.1 . Following the firms with a Class III event (the most severe), the trend line was steeper. Still, the stock price did not recover and the CAARs reached roughly -0.17 within 90 days after the event. Such a result suggests that its negative effect is persistent when a product-harm event with a Class III hazard occurs. Therefore, the duration of the negative reactions varied with the severity of product-harm crises. This result provides evidence to further support $\mathrm{H} 2 \mathrm{a}$ and $\mathrm{H} 2 \mathrm{~b}$.

\subsubsection{The Difference of Negative Effects Based on Brand} Equity. As the negative effect of a firm with Class III hazard is persistent and significant, this section compares the 25 firms experiencing the lowest drops in stock prices with 25 firms having the highest drops in stock prices, based on brand equity. These drops in stock returns are measured during the event window $(-5,+1)$ by the market model.

Brand equity has been defined as an added value that is given to a product $[57,58]$. More comprehensively, brand equity is identified as the brand value that stems from a high level of brand loyalty, perceived quality, name recognition, and strong brand associations as well as assets related to the 
TABLE 5: CARs being affected by incidence/severity of product-harm crises.

\begin{tabular}{|c|c|c|c|c|}
\hline Panel A Dep. variables CARs & $\begin{array}{l}\text { CARs from Fama3 } \\
(1)\end{array}$ & $\begin{array}{c}\text { CARs from Fama5 } \\
(2)\end{array}$ & $\begin{array}{c}\text { CARs from e-period model } \\
(3)\end{array}$ & $\begin{array}{l}\text { CARs from market model } \\
(4)\end{array}$ \\
\hline Incidence/severity & $\begin{array}{c}-0.025^{* *} \\
(0.017)\end{array}$ & $\begin{array}{c}-0.023^{* * *} \\
(0.010)\end{array}$ & $\begin{array}{c}-0.008^{* *} \\
(0.014)\end{array}$ & $\begin{array}{c}-0.008^{* * *} \\
(0.003)\end{array}$ \\
\hline Book to market & $\begin{array}{c}0.004 \\
(0.246)\end{array}$ & $\begin{array}{c}0.001 \\
(0.790)\end{array}$ & $\begin{array}{c}0.004 \\
(0.420)\end{array}$ & $\begin{array}{l}0.007^{*} \\
(0.092)\end{array}$ \\
\hline Control variables & Yes & Yes & Yes & Yes \\
\hline \multicolumn{5}{|c|}{ Panel B instrument in the first stage } \\
\hline Book leverage & $\begin{array}{r}-1.023^{*} \\
(0.071)\end{array}$ & $\begin{array}{r}-0.996^{*} \\
(0.079)\end{array}$ & $\begin{array}{c}-0.911^{*} \\
(0.096)\end{array}$ & $\begin{array}{r}-0.995^{*} \\
(0.071)\end{array}$ \\
\hline Size & $\begin{array}{c}-0.396^{* *} \\
(0.031)\end{array}$ & $\begin{array}{c}-0.408^{* *} \\
(0.026)\end{array}$ & $\begin{array}{c}-0.379^{* *} \\
(0.015)\end{array}$ & $\begin{array}{c}-0.351^{* *} \\
(0.026)\end{array}$ \\
\hline Sales & $\begin{array}{c}0.532^{* * *} \\
(0.001)\end{array}$ & $\begin{array}{c}0.535^{* * *} \\
(0.001)\end{array}$ & $\begin{array}{c}0.487^{* * *} \\
(0.000)\end{array}$ & $\begin{array}{c}0.496^{* * *} \\
(0.000)\end{array}$ \\
\hline Number of suppliers & $\begin{array}{r}-0.055 \\
(0.180)\end{array}$ & $\begin{array}{r}-0.055 \\
(0.187)\end{array}$ & $\begin{array}{c}-0.047^{* * *} \\
(0.215)\end{array}$ & $\begin{array}{l}-0.047 \\
(0.218)\end{array}$ \\
\hline $\begin{array}{l}\text { Industry dummies } \\
\text { Observations }\end{array}$ & $\begin{array}{c}\text { 1-level INC } \\
398\end{array}$ & $\begin{array}{l}\text { 1-level INC } \\
397\end{array}$ & $\begin{array}{l}\text { 1-level INC } \\
391\end{array}$ & $\begin{array}{c}\text { 1-level INC } \\
392\end{array}$ \\
\hline Wald & $\begin{array}{l}38.29^{* * *} \\
(0.0014)\end{array}$ & $\begin{array}{l}30.97^{* * *} \\
(0.0089)\end{array}$ & $\begin{array}{l}51.29^{* * *} \\
(0.0000)\end{array}$ & $\begin{array}{c}1636.95^{* * *} \\
(0.0000)\end{array}$ \\
\hline
\end{tabular}

Table 5 shows results for the cross-sectional analyses of the $(-1,+10)$ CARs from the Fama-French three-factor model and the Fama-French five-factor model, and the $(-5,+1)$ CARs from the e-period model (Compared to estimation period) and the market model during our sample period. Incidence is an endogenous variable. It is set to 1 for firms in the product-harm sample, and 0 for the control sample. Severity is an ordered rank variable, which is set to one, two, or three for firms in the product-harm samples according to the severity of the event, and zero for control firms. All estimations include year dummies and 1-level INC. Column (1) and Column (2) are the results run in the Fama3 and Fama5 models, respectively, and Incidence is the endogenous variable. Column (3) and Column (4) are the results run in the e-period model and the market model, respectively, and Severity is the endogenous variable. Presented $P$-values in the parentheses are based on heteroskedasticity robust standard errors and are clustered by firm. ${ }^{* * *},{ }^{* *}$, and ${ }^{*}$ indicate significance at $1 \%, 5 \%$, and $10 \%$, respectively.

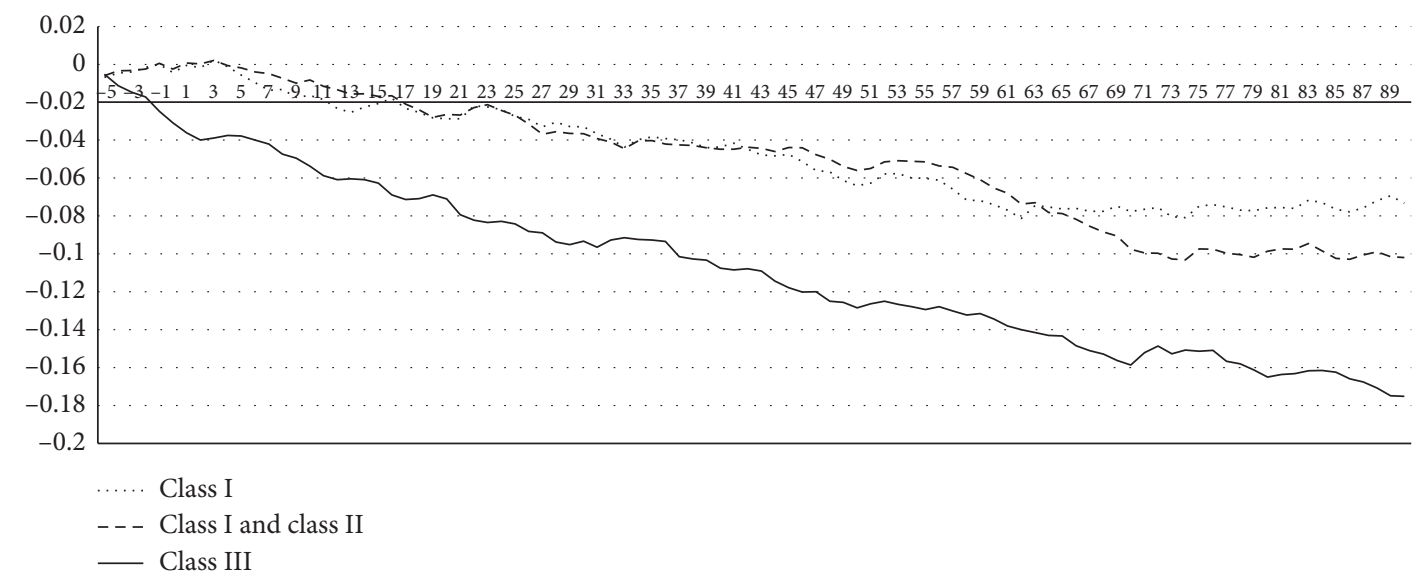

FIGURE 1: Cumulative average abnormal returns over time.

brand, such as trademarks, patents, and distribution channels [59]. This paper thereby treats brand equity and brand value equally. Also, these two terms can be used interchangeably and high brand equity means a valuable brand [60]. Furthermore, higher brand equity of a firm is called strong brand, otherwise it is a weak brand.

In the product-harm research, there exist two different claims regarding the effect of brand equity. Some scholars found that brand equity buffers against the negative impact, but others claimed that brand equity is a liability when faced with crises. For instance, some research has found that strong brands are less vulnerable to the negative impact of corporate crises [19-21]. But some literature documents that higher brand equity means higher expectation, which can be a trouble in case of a product-harm event $[27,28]$. Then, this section examines whether high brand equity can resist the harmful effect of product-harm crises in China from a investor perspective.

Next, this section identifies those brands that appeared on the China's 500 Most Valuable Brands (CMVB) list at least once from our sample period as strong brands [20]. The remaining brands are classified as weak brands. It sets a dichotomous variable that takes the value 1 to present a strong brand and 0 otherwise. Among the firms with lowest 


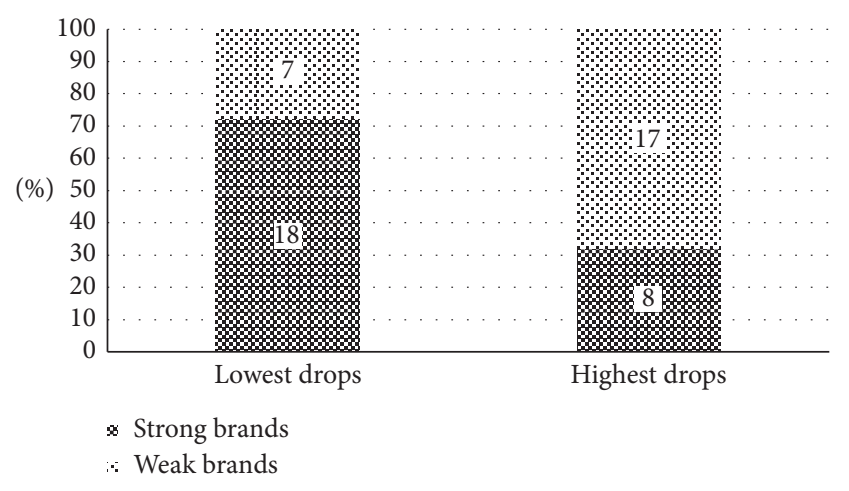

Figure 2: The difference of CARs affected by firms' brand equity.

drops in the stock price, 18 firms are strong brands, accounting for $72 \%$. In another group, 17 firms are weak brands, accounting for $68 \%$. These findings in Figure 2 suggest that strong brands can resist the negative effect of the severe hazards. In the long run, building a strong brand is very valuable. It can not only mitigate event risks but also benefit firms and investors.

\section{Conclusion}

Under the concept of green development, this study focuses on the initial stage of the product-harm crises to prevent secondary pollution caused by product recall or product disposal. To disentangle the effect of the inherent characteristics of firms from incidence/severity of the productharm crises, it utilizes the two-stage procedure to control for this endogenous issue.

Firstly, this paper documents that firms hit by productharm crises usually have a higher debt, and those with higher leverage are less likely to be mired by product-harm crises. Furthermore, such firms are less likely to undergo serious crises. These findings imply that higher leverage can encourage managers and organizations to focus on product issues. Moreover, results show that a large firm is less likely to have crises. This result is contrary to that of extant research [43]. An explanation is that a large firm might have more to lose from product-harm crises than a smaller firm. Hence, the probability of incidence and the severity of crises should decrease in larger firms, compared to smaller firms.

Secondly, the results of this study demonstrate that the incidence and severity of product-harm crises have a significant impact on the stock prices. Although previous literature has examined the effects of the incidence and severity of product recall on stock market $[4,23]$, little research has been conducted on the financial effect of initial crisis rather than its recovery strategy. Also, this paper demonstrates the financial effect of the incidence and severity of product-harm crises and offers a precise "size" of negative effect of its initial crisis. Results show that investors react adversely to productharm crises. Furthermore, the drops in stock price are positively associated with the severity of product hazards. The result shows that firms with high potential growth appear to have more negative stock prices. This implies that growth firms should take some appropriate actions to reassure investors. For instance, such firms can announce specific remedies for product issues when faced with product-harm crises.

Moreover, regarding the differences of CARs over time based on its severity, the duration of the negative reactions varied with the severity of product-harm crises. Results show that its negative effect is persistent when faced with the most severe crisis. If they are not life-threating crises, the losses in the stock market will stop in the near future. These findings help firms to better understand the financial loss brought by crisis over time, because most studies regard time as a control variable, and limited studies consider the effect over time [8]. Then this paper firstly considers the buffer effect of brand equity from investors' perspective. Results confirm that brand equity can mitigate the negative effect in case of serious crisis. Such results give a new support for the fact that brand equity is a buffer rather than a trouble when faced with a crisis $[19,21,26,27]$.

In short, this paper evaluates the probability of a firm being influenced by incidence/severity of a crisis. Then, results find that firms with higher debt, lager size, and small sales are less likely to undergo product-harm crises. This provides new ideas for firms to better implement low-carbon economy and green development. After that, it explores the financial effects of incidence and severity of product-harm crises as well as the potential growth. Next, this paper analyzes the differences of CARs in cross section and that over time based on its severity. Our findings give new insights for firms to improve product performance amid the green context. Furthermore, the findings present some ways to enhance firm value in complex social networks.

\section{Data Availability}

The data used to support the findings of this study are available from the corresponding author upon request.

\section{Conflicts of Interest}

The authors declare that they have no conflicts of interest.

\section{Acknowledgments}

This work was supported by the National Natural Science Foundation of China (Grant no. 71773024), the Natural Science Foundation of Heilongjiang Province of China (Grant no. G2018006), and the Heilongjiang Postdoctoral Scientific Research Developmental Fund (Grant no. LBHQ18064).

\section{References}

[1] C. Wang, Q. Zhang, and W. Zhang, "Corporate social responsibility, green supply chain management and firm performance: the moderating role of big-data analytics capability," Research in Transportation Business and Management, vol. 37, 2020.

[2] W. Zhang, M. Zhang, W. Zhang, Q. Zhou, and X. Zhang, "What influences the effectiveness of green logistics policies? a 
grounded theory analysis," Science of the Total Environment, vol. 714, 2020.

[3] N. Dawar and M. M. Pillutla, "Impact of product-harm crises on brand equity: the moderating role of consumer expectations," Journal of Marketing Research, vol. 37, no. 2, pp. 215-226, 2000.

[4] X. Zhao, Y. Li, and B. B. Flynn, "The financial impact of product recall announcements in China," International Journal of Production Economics, vol. 142, no. 1, pp. 115-123, 2013.

[5] T. Coombs and S. Holladay, "CSR as crisis risk: expanding how we conceptualize the relationship," Corporate Communications, vol. 20, no. 2, p. 144, 2015.

[6] M. J. Gijsenberg, H. J. Van Heerde, and P. C. Verhoef, "Losses LoomLongerthan gains: modeling the impact of service crises on perceived service quality over time," Journal of Marketing Research, vol. 52, no. 5, pp. 642-656, 2015.

[7] R. Song, H. Kim, G. M. Lee, and S. Jang, "Does deceptive marketing pay? the evolution of consumer sentiment surrounding a pseudo-product-harm crisis," Journal of Business Ethics, vol. 158, no. 3, pp. 743-761, 2019.

[8] M. Khamitov, Y. Grégoire, and A. Suri, "A systematic review of brand transgression, service failure recovery and productharm crisis: integration and guiding insights," Journal of the Academy of Marketing Science, vol. 48, no. 3, pp. 519-542, 2020.

[9] H. Gao, J. Xie, Q. Wang, and K. C. Wilbur, "Should ad spending increase or decrease before a recall announcement? the marketing-finance interface in product-harm crisis management," Journal of Marketing, vol. 79, no. 5, pp. 80-99, 2015.

[10] Y. Liu, V. Shankar, and W. Yun, "Crisis management strategies and the long-term effects of product recalls on firm value," Journal of Marketing, vol. 81, no. 5, pp. 30-48, 2017.

[11] A. X. Liu, Y. Liu, and T. Luo, "What drives a firm's choice of product recall remedy? the impact of remedy cost, product hazard, and the CEO," Journal of Marketing, vol. 80, no. 3, pp. 79-95, 2016.

[12] O. Trendel, M. Mazodier, and K. D. Vohs, "Making warnings about misleading advertising and product recalls more effective: an implicit attitude perspective," Journal of Marketing Research, vol. 55, no. 2, pp. 265-276, 2018.

[13] S. He, H. Rui, and A. B. Whinston, "Social media strategies in product-harm crises," Information Systems Research, vol. 29, no. 2, pp. 362-380, 2018.

[14] J. Wei, M. Zhao, F. Wang, and D. Zhao, “The effects of firm actions on customers' responses to product recall crises: analyzing an automobile recall in China," Journal of Risk Research, vol. 19, no. 4, pp. 425-443, 2016.

[15] K. Cleeren, "Using advertising and price to mitigate losses in a product-harm crisis," Business Horizons, vol. 58, no. 2, pp. 157-162, 2015.

[16] K. Karande and M. Gopinath, "Protecting brands from product failure using extended warranties," Journal of Product \& Brand Management, vol. 28, no. 7, pp. 787-799, 2019.

[17] C.-Y. Yin, H.-Y. Yu, and P. Poon, "Consumers' attributions and brand evaluations in product-harm crises: the role of implicit theories of personality," Journal of Consumer Behaviour, vol. 15, no. 1, pp. 87-95, 2016.

[18] V. S. Thaler, U. Herbst, and M. A. Merz, "A real product scandal's impact on a high-equity brand: a new approach to assessing scandal impact," Journal of Product \& Brand Management, vol. 27, no. 4, pp. 427-439, 2018.
[19] B. Rea, Y. Stoner, and J. Stoner, "When a brand caught fire: the role of brand equity in product-harm crisis," Journal of Product \& Brand Management, vol. 23, no. 7, pp. 532-542, 2014.

[20] L. Hsu and B. Lawrence, "The role of social media and brand equity during a product recall crisis: a shareholder value perspective," International Journal of Research in Marketing, vol. 33, no. 1, pp. 59-77, 2016.

[21] Y. Zhao, Y. Zhao, and K. Helsen, "Consumer learning in a turbulent market environment: modeling consumer choice dynamics after a product-harm crisis," Journal of Marketing Research, vol. 48, no. 2, pp. 255-267, 2011.

[22] J. Lei, N. Dawar, and Z. Gürhan-Canli, "Base-rate information in consumer attributions of product-harm crises," Journal of Marketing Research, vol. 49, no. 3, pp. 336-348, 2012.

[23] J. Ni, B. B. Flynn, and F. R. Jacobs, "The effect of a toy industry product recall announcement on shareholder wealth," International Journal of Production Research, vol. 54, no. 18, pp. 5404-5415, 2016.

[24] E. F. Fama and K. R. French, "A five-factor asset pricing model," Journal of Financial Economics, vol. 116, no. 1, pp. 1-22, 2015.

[25] K. Cleeren, M. G. Dekimpe, and H. J. Van Heerde, "Marketing research on product-harm crises: a review, managerial implications, and an agenda for future research," Journal of the Academy of Marketing Science, vol. 45, no. 5, pp. 593-615, 2017.

[26] M. Yu, F. Liu, J. Lee, and G. Soutar, "The influence of negative publicity on brand equity: attribution, image, attitude and purchase intention," Journal of Product \& Brand Management, vol. 27, no. 4, pp. 440-451, 2018.

[27] P. R. Darke, L. Ashworth, and K. J. Main, "Great expectations and broken promises: misleading claims, product failure, expectancy disconfirmation and consumer distrust," Journal of the Academy of Marketing Science, vol. 38, no. 3, pp. 347-362, 2010.

[28] M. Rhee and P. R. Haunschild, "The liability of good reputation: a study of product recalls in the U.S. automobile industry," Organization Science, vol. 17, no. 1, pp. 101-117, 2006.

[29] G. Jarrell and S. Peltzman, "The impact of product recalls on the wealth of sellers," Journal of Political Economy, vol. 93, no. 3, pp. 512-536, 1985.

[30] B. M. Barber and M. N. Darrough, "Product reliability and firm value: the experience of American and Japanese automakers, 1973-1992," Journal of Political Economy, vol. 104, no. 5, pp. 1084-1099, 1996.

[31] S. Thirumalai and K. K. Sinha, "Product recalls in the medical device industry: an empirical exploration of the sources and financial consequences," Management Science, vol. 57, no. 2, pp. 376-392, 2011.

[32] Y. Chen, S. Ganesan, and Y. Liu, "Does a firm's product-recall strategy affect its financial value? an examination of strategic alternatives during product-harm crises," Journal of Marketing, vol. 73, no. 6, pp. 214-226, 2009.

[33] J. Brander and T. Lewis, "Oligopoly and financial structure," American Economic Review, vol. 76, no. 5, pp. 956-970, 1986.

[34] V. Maksimovic, Optimal capital structure in oligopolies, Ph.D. dissertation, Harvard University, Cambridge, MA, USA, 1986.

[35] T. R. Beard, "Bankruptcy and care choice," The RAND Journal of Economics, vol. 21, no. 4, pp. 626-634, 1990.

[36] M. C. Jensen, "Agency costs of free cash flow, corporate finance, and takeover," American Economic Review, vol. 76, pp. 323-329, 1986. 
[37] M. Campello and Z. Fluck, "Product market performance, switching costs, and liquidation values: the real effects of financial leverage," in Proceedings of the AFA 2007 Chicago Meetings Paper, Chicago, IL, USA, January 2007.

[38] E. Dedman and S. W.-J. Lin, "Shareholder wealth effects of CEO departures: evidence from the UK," Journal of Corporate Finance, vol. 8, no. 1, pp. 81-104, 2002.

[39] D. Kahneman and A. Tversky, "Prospect theory: an analysis of decision under risk," Econometrica, vol. 47, no. 2, pp. 263-291, 1979.

[40] E. T. Cheah, W. L. Chan, and C. L. L. Chieng, "The corporate social responsibility of pharmaceutical product recalls: an empirical examination of U.S. And U.K. markets," Journal of Business Ethics, vol. 76, no. 4, pp. 427-449, 2007.

[41] R. W. Rogers, "A protection motivation theory of fear appeals and attitude change1," The Journal of Psychology, vol. 91, no. 1, pp. 93-114, 1975.

[42] A. J. Hoffman and W. Ocasio, "Not all events are attended equally: toward a middle-range theory of industry attention to external events," Organization Science, vol. 12, no. 4, pp. 414-434, 2001.

[43] O. Kini, J. Shenoy, and V. Subramaniam, "Impact of financial leverage on the incidence and severity of product failures: evidence from product recalls," The Review of Financial Studies, vol. 30, no. 5, pp. 1790-1829, 2017.

[44] S. R. Jory, T. N. Ngo, D. Wang, and A. Saha, "The market response to corporate scandals involving CEOs," Applied Economics, vol. 47, no. 17, pp. 1723-1738, 2015.

[45] M. A. Lyles, B. B. Flynn, and M. T. Frohlich, "All supply chains don't flow through: understanding supply chain issues in product recalls," Management and Organization Review, vol. 4, no. 2, pp. 167-182, 2008.

[46] S. Armitage, "Event study methods and evidence on their performance," Journal of Economic Surveys, vol. 9, no. 1, pp. 25-52, 2010.

[47] J. Binder, "The event study methodology since 1969," Review of Quantitative Finance and Accounting, vol. 11, no. 2, pp. 111-137, 1998.

[48] E. Boehmer, J. Masumeci, and A. B. Poulsen, "Event-study methodology under conditions of event-induced variance," Journal of Financial Economics, vol. 30, no. 2, pp. 253-272, 1991.

[49] A. C. Mackinlay, "Event studies in economics and finance," Journal of Economic Literature, vol. 35, no. 1, pp. 13-39, 1997.

[50] L.-T. Hsu and S. Jang, "The postmerger financial performance of hotel companies," Journal of Hospitality \& Tourism Research, vol. 31, no. 4, pp. 471-485, 2007.

[51] H. Miyajima and Y. Yafeh, "Japan's banking crisis: an eventstudy perspective," Journal of Banking \& Finance, vol. 31, no. 9, pp. 2866-2885, 2007.

[52] S. Seo, S. Jang, L. Miao, B. Almanza, and C. Behnke, "The impact of food safety events on the value of food-related firms: an event study approach," International Journal of Hospitality Management, vol. 33, pp. 153-165, 2013.

[53] E. F. Fama and K. R. French, "Size, value, and momentum in international stock returns," Journal of Financial Economics, vol. 105 , no. 3, pp. 457-472, 2012.

[54] N. Christopeit, "Wooldridge, J. M.: econometric analysis of cross section and panel data. XXIII, 752 pp. MIT press, Cambridge, Mass., 2002. Hardcover $£$ 37.50," Journal of Economics, vol. 80, no. 2, pp. 206-209, 2003.

[55] J. A. Dubin and D. L. Mcfadden, "An econometric analysis of residential electric appliance holdings and consumption," Econometrica, vol. 52, no. 2, pp. 345-362, 1984.
[56] D. M. Roodman, "Fitting fully observed recursive mixedprocess models with CMP," Working Papers, vol. 11, no. 2, pp. 159-206, 2009.

[57] G. Biedenbach, P. Hultén, and V. Tarnovskaya, "B2B brand equity: investigating the effects of human capital and relational trust," Journal of Business \& Industrial Marketing, vol. 34, no. 1, pp. 1-11, 2019.

[58] S. Y. Duncan, R. Chohan, and J. J. Ferreira, "What makes the difference? employee social media brand engagement," Journal of Business \& Industrial Marketing, vol. 34, no. 7, pp. 1459-1467, 2019.

[59] N. S. Davcik, R. Vinhas Da Silva, and J. F. Hair, "Towards a unified theory of brand equity: conceptualizations, taxonomy and avenues for future research," Journal of Product \& Brand Management, vol. 24, no. 1, pp. 3-17, 2015.

[60] M. O. R. De Oliveira, A. A. Stefanan, and M. L. Lobler, "Brand equity, risk and return in Latin America," Journal of Product \& Brand Management, vol. 27, no. 5, pp. 557-572, 2018. 